\title{
12 Historicising Political Masculinities and Careers
}

\begin{abstract}
This chapter focuses on a period in history in which 'being a politician' developed into a career-path, as representative politics became a matter of professional skill and expertise rather than a leisurely gentlemanly pursuit. It attempts to chart some ways in which the male career politician can be historicised, drawing on examples from the Belgian parliament in the long nineteenth century. Most importantly, it aims to show how this project of the 'historicisation' of masculinities and careers may be useful beyond the confines of the past, and how historical approaches can inform contemporary analyses of gender, the workplace, and gendered practices of political work. The chapter sketches how historians have adopted and adapted the influential model of 'hegemonic' masculinity and how it can be used to study modern (i.e. nineteenth and early twentieth century) careers in representative politics. From this vantage point, it reflects on the terminology of masculinity and its cultural work, how the vocabulary around it has changed and how contemporary concepts used in cultural, sociological and anthropological research can (and sometimes cannot) be mobilised for the study of particular histories. Focusing on the history of politics as an arena of professionalisation and (therefore) as a context in which masculinities were constructed and performed, the chapter aims to offer alternative analytical frameworks to understand both gender and career as processes subject to significant change.
\end{abstract}

\section{Introduction}

In 1849, French caricaturist Honoré Daumier drew and published a series of humorous images he entitled "Physionomie de l'Assemblée" ("Faces of Parliament"). The series shows a number of 'characters' to be observed from the gallery in the hemicycle such as that of Frédéric Lagrange (Figure 1). They show speakers orating, losing their patience, huffing like petulant children and gossiping frivolously. It is, all in all, not a very dignified depiction of a group of people who, as Marnix Beyen (2006) has pointed out, set great store by dignity and who increasingly defined their activities in parliament as an occupation or profession (De Smaele 2002). Although 'work' in politics would remain a matter for the wealthy elites throughout most of the nineteenth century, being a 


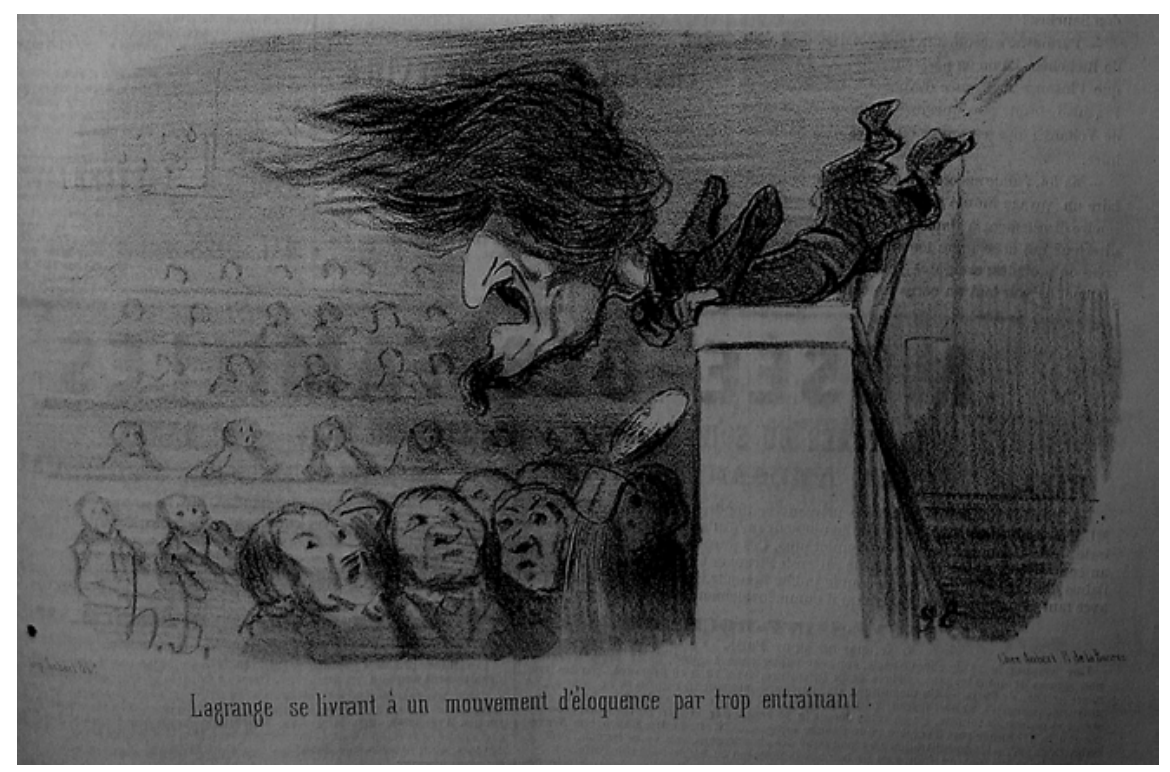

Figure 1: H. Daumier, “ Lagrange carried away by a sudden, unprepared impulse of eloquence. ”, Satirical image of a political representative at work, by Honoré Daumier. DR Number 1952 C www. daumier.org.

political actor in a representative democracy was not the natural result of belonging to the landed gentry. It required effort (to convince voters and fellow representatives), as well as service (to constituents and to the state) (Lauwers 2019). It had, in other words, become 'work' and came with reputational and potentially financial rewards as well as risks. It also increasingly showed different degrees of success between different hopefuls: some 'applicants' for the job of representative would come to have a long career in politics, and some would not. This is, essentially, what Daumier was showing and lampooning in his series. "Physionomie de l'Assemblée" humorously asked who had 'what it takes' to be a representative in a modern, parliamentary political system.

The actions, personalities and characteristics of nineteenth-century representatives in Europe's parliaments are hardly obscure. These are exactly the kind of 'great men' history has traditionally been written about. However, the focus of such histories has generally been on their ideas, the political decisions they made, the effect they had on policy or social change: they have been studied as making a mark on the world. It is only more recently that historians have shifted their attention to the more mundane, day-to-day practices and the less exceptional characteristics that also helped to make a political career. It mattered, 
for example, as a number of social historians have shown, that all these (almost exclusively white and European) men hailed from a rather exalted social class and it mattered that well into the twentieth century they were indeed exclusively men (recently, e.g. Richter and Wolff 2018). As Daumier's caricatures show, the parliamentary 'dignity' he satirised was heavily modulated by gender and class (as well as ability and race, even if those may be less visible). Comparing his "physionomie de l'Assemblée" with another series on politically active women ("Les Bas Bleus", the Bluestockings) shows stark differences in how male and female political practice could be imagined, depicted and ridiculed. It also mattered that these men were active at a time when 'being a politician' became a career-path of sorts: their histories can and should also be studied in the context of the rise of upper-middle-class occupations and their professionalisation - a process that has been connected to changes in the discourses and practices of masculinity (as shown by, e.g. Ellis 2014). Much like science, medicine and law, the field of politics would increasingly become a matter of skill and expertise rather than a leisurely gentlemanly pursuit. This process developed in close interaction with changes in the ideals and practices of upper- and middleclass gendered embodiment as well as the rise of modern domesticity (Tosh 2007; Davidoff and Hall 1987). Men with political careers may have largely steered world politics, but the shape of those careers was forged on a far less grand stage, often much closer to home.

In what follows, I will attempt to chart out some ways in which the male career politician can be historicised in this manner, drawing on examples from the Belgian parliament in the long nineteenth century. ${ }^{1}$ First, I will examine how historians have adopted and adapted the influential model of 'hegemonic' masculinity and how it can be used to study modern (i.e nineteenth and early twentieth century) careers in representative politics. Second, I will reflect on the terminology of masculinity and its cultural work, how the vocabulary around it has changed and how contemporary concepts used in cultural, sociological and anthropological research can (and sometimes cannot) be mobilised for the study of particular histories. The third and final section of the paper will zoom in on how historical approaches to men and masculinities can offer alternative analytical frameworks to understand gender as a 'process' and how this may aid

1 The choice for these cases is somewhat arbitrary: the Belgian parliamentary context is simply the one I am most familiar with. However, the Belgian case does present an interesting 'laboratory' for modern democracy in this period, as both country and legislative chamber were founded on explicitly modern principles, in 1830, and are therefore somewhat less guided by older national political traditions, as is the case for Britain and France. Background on the political history of Belgium can be found e.g. in Witte e.a. 2009. 
in contextualising contemporary notions of masculinity and work. Most importantly, across these three sections, I hope to provide a rudimentary roadmap to existing practices of the historicisation of masculinity.

\section{Hegemonic and Other Masculinities}

As has been pointed out by various historians of gender and women, the history of masculinity is not so much unwritten as 'unmarked' (Dudink 1998): many forms of history writing have focused on great men and their great deeds. This seems true both for the heroic accounts of history in pre-modern times and for the histories written by the first generations of professional historians whose reliance on legal and political documents led to a renewed focus on the thoughts and actions of 'important men' (and who imagined their own profession as intrinsically masculine as well, Schnicke 2015; Smith 2000). It is only with the rise of women's history (and later gender history, Scott 1986) that it became clear that writing 'herstory' would not immediately lay bare the intrinsically gendered nature of the discipline's questions, methods and underlying assumptions. Throughout the 1980's and 90's, early attempts to historicise the men's lives next to which 'women's history' was taking place did appear, if in a somewhat fragmented fashion (e.g. Frevert 1991; Nye 1993; Theweleit 1977; Hall 1992; Rotundo 1993; Mosse 1996; Kimmel 1996; Griswold 1993; Delumeau and Roche 1990; Knibiehler 1987; Lenzen 1991). ${ }^{2}$ Unsurprisingly, most of this work focuses either on the spaces where men and women were most intimately

2 Whilst numerous disciplines engage with the past as part of their enquiries in some way or other, it is perhaps useful here to point to a particularity of the historical discipline, in which understanding past processes, events or phenomena by 'historicising' (i.e. placing them in their historical context which is understood on its own terms) them is central. Or, as John Tosh puts it in an influential history primer, the historian's goal is always to show and cultivate historical awareness. "History as a disciplined enquiry aims to sustain the widest possible definition of memory, and to make the process of recall as accurate as possible, so that our knowledge of the past is not confined to what is immediately relevant. The goal is a resource with open-ended application, instead of a set of mirror-images of the present" (Tosh 2015). This does not imply that the outcomes of historical enquiry are completely divorced from current questions or concerns, but rather that current categories of thought are not assumed to exist or have 'mirror-images' in the past. For this volume, that would include categories such as gender, ethnicity or class: a historical approach would not 'look back' from the present and chart changes in the content or limits of those categories, but rather study societies in which these categories are absent, or in the process of emerging. 
brought together (the home) or those where women were very explicitly excluded and boys were understood to 'become' men (most notably the army).

It is only from the mid-1990s onward that the question of masculinity (or masculinities) in history started to be asked systematically as a critically and historically relevant question. This was part of a more general move toward the critical study of 'elites' in response to the social histories of the lower classes, subalterns, disabled subjects, women, and others, that had been written since the 1960s (Handley, McWilliam and Noakes 2018). As Harry Brod (2002) has pointed out, masculinity studies can be approached as 'superordinate' studies. However, the appearance of an influential article by Victorianist and historiographer John Tosh, discussing the potential application of R.W. Connell's (1995) model of multiple and hegemonic masculinities to the study of history, played an important role in shifting historians' attention to masculinity as well - particularly in the English-speaking world (Tosh 1994). When Tosh asked "What Should Historians Do With Masculinity?", he pointed to some of Connell's analytical tools for an answer (particularly for the study of modern masculinities) but also drew attention to some of the specifically historical challenges to be tackled when studying masculinities in the past. His critical appraisal of the model of hegemonic masculinity as well as his work in adopting and adapting the model for historical research was followed up and expanded upon in several 'reviews' of the nascent field of the history of masculinity in the early 2000’s (Francis 2002; Traister 2000; Harvey and Shepard 2005).

Since its publication, historians have taken up Tosh's suggestion that they should, indeed, 'do' something with masculinity with enthusiasm, and have continued to grapple with the challenge of applying Connell's Gramscian model of a hegemonic masculinity among other, plural, masculinities to historical cultures and societies, much like gender scholars, anthropologists and sociologists have continued to critique and refine Connell's model, which was reformulated most notably by the author herself in collaboration with James Messerschmidt in 2005 (Connell and Messerschmidt 2005). Meanwhile, other approaches to masculinity have also continued to yield interesting historical analysis for the modern period - sometimes in conversation, response or contradiction to the 'hegemonic' model (e.g. Frevert 2001; Rauch 2000; Corbin, Courtine and Vigarello 2009; Surkis 2006; Hagemann 2002; Solomon-Godeau 1997). Whilst older (pre-Marxist and pre-Darwinian) periods offer a very challenging context for this model, the more general notion that plural masculinities defined by the hierarchies among them (and not just between men and women) has proven to be a helpful perspective for these periods as well (e.g. Dinges et al. 2005; Lees 1994; Shepard 2006; Mazo Karras 2002). At the same time, studies of masculinity in all periods of history, including industrialised modernity, have shown problems in 
adapting Connell's model to study the past and tried to come up with alternatives. The most thorough re-imagination of (hegemonic) masculinity 'as a category of historical analysis' is perhaps Ben Griffin's (2018) recent adoption and adaptation in Gender \& History. "Hegemonic Masculinity as a Historical Problem" shows why the model of multiple and hierarchically organised masculinities has been so attractive to historians (Griffin 2018, 379). But it also lays bare a number of particularly historical ways in which the model is 'problematic' (380).

Building on critiques such as those of John Tosh, Alexandra Shepard and other historians, Griffin sets out to develop a new set of approaches to study masculinity in history. Its aim is to reconsider, rather than reject, the concept of hegemony, and to address some of the problems historians have faced in applying Connell's concept outright by offering an alternative framework to think about the power-relations between men. One that would enable us to deal with the main problems historians of masculinity seem to run into: societal specificity (how can a Marxist model work in a pre-capitalist society, for example), and fluidity (or more precisely: change over time, including significant change over long periods of time $\mathrm{e}^{3}$ - the central problem to any historical study). As such, his alternative framework does not consist of the formation of 'identities' or places within a hierarchical constellation of power, but rather of different 'processes' in which 'being a man' always appears as already in flux, as constantly changing. It therefore recognises that 'practices' and 'performances' of masculinity not only change slowly over time (as norms and expectations change) but also that "individual men do not continually perform the same masculinity" (384). The cultural work that goes into creating historically contingent masculinities is therefore not only performed by societies, but also by individuals (of all genders) and above all within particular communication communities, and is interpretative as well as performative (387). In other words, masculinity is performed in front of a particular

3 One important note to make here is that for a large part of history gender (as well as ethnicity or race) was not imagined to be a 'biological' category, and therefore the important work of 'deconstructing' gender and race, or showing their cultural, political, 'non-biological' character, necessarily takes on a different form. I will come back to the rise of the 'two-sex' model later in this paper. For now, it bears remembering that many categories that are now analysed as 'intersecting' with gender either only came into existence in the modern period (class, for example, exists in industrialized societies) or could not be imagined as free-standing or 'biological' categories (race, for example, was explained in terms of environmental determinism rather than biology until well into the nineteenth century; estate meant very different things for differently gendered and aged individuals). 
(and co-constructive) audience of people with whom one shared ideas, norms, vocabularies, and indeed space. ${ }^{4}$ Studying such a history of masculinity is, according to Griffin, “a fourfold operation”.

First, there is the process of cultural contestation whereby certain forms of masculinity are valorised [. . .]. Second, there is the process whereby access to the mechanisms that allow men to identify themselves with those masculinities is unequally distributed among members of that communication community. Third, there is the process by which the performance of a particular masculinity is accorded recognition by others [. . .]. The fourth operation of power occurs after this process of recognition: having been identified with a particular form of masculinity, the individual is then positioned in relation to sets of institutional practices, rewards and sanctions.

(Griffin 2018, 387)

The consistent focus on 'processes' is important here: certain forms of masculinity 'are valorised' within particular communication communities, and that valorisation is a process, rather than a situation in which men find themselves. So is the unequal distribution of access to identification with certain embodiments of power: rather than being expressed by a category intersecting with gender (such as class, ability, ethnicity), the focus is on the process of distribution itself - this is most clearly exemplified in the way the framework opens up ways to also think of the way age (a category that even now, in times of biological determinism, is never understood as static) modulates and shapes performances and readings of masculinity. Focusing on such broadly defined processes does not offer clear 'concepts' precisely because it refuses to define or even name 'categories' that can be deployed over time. Rather it recognises that, as L.P. Hartley famously put it "the past is a foreign country, they do things differently there" - and those things include understanding, experiencing and 'doing' what constituted being a man.

So how do these frameworks apply to the masculinity that we are interested in here? Arguably, the modern professional politician or parliamentary representative is one of the most often and most closely analysed figures in history. Aside from the many 'great man'-type histories that have been written about statesmen, recent works on their gendered practices and characteristics have largely led the way in establishing the history of masculinity (next to prolific work on military men, and far fewer on e.g. farmers or labourers) (e.g. Kennedy and McCormack 2007; Dudink, Hagemann and Tosh 2004; Dudink, Hagemann and Tosh 2007; Griffin 2012; Hoegaerts 2014). In many ways, these modern and

4 Griffin borrows the notion of communication communities from Simon Szreter (1995), thereby recognizing that speaking of any hegemonic culture before the rise of mass communication is difficult. "This concept recognises the variegated and uneven dissemination of particular sets of cultural norms and relates this to the historically specific mechanisms of socialisation through which those norms were propagated" (Griffin 2018, 9). 
powerful men seem to lend themselves perfectly to an analysis in terms of hegemony: they lived in a capitalist and industrialised world, and were concerned with power and competition (not to mention very aware of their own exalted position in regard to other men). Yet, as almost all existing studies on 'political' masculinities have shown, things are rarely that simple. Despite their obvious positions of power, late nineteenth-century politicians, particularly, grappled with the rising norm of physical fitness and strength that would become more closely connected to 'natural' definitions of masculinity in the run-up to the First World War (Mangan 2000; Roper 2005; Hoegaerts 2012). And even if their bodies did not get in the way of achieving gendered normality, the varied and fluid performances of self these political men engaged in in the nineteenth century show how undefined and changeable that normality was in the first place. It contained dignified silence as well as rousing oratory, competitive aggression as well as rational control of one's emotions, total devotion to one's country and profession as well as a strong identification with fatherhood, and so on.

These simultaneous and contradictory demands attached to (modern) masculinity have been described as a 'double bind' (Bordo 1999). Although these intrinsic tensions can be acknowledged (and have been, notably by Connell) in the very notion of hegemonic masculinity (which represents a societal norm that, whilst upheld by individual men, cannot be put into practice by any individual), the model of hegemony/complicity/marginality does not really offer us clear tools to analyse the different and changeable ways in which men have negotiated this double bind. It is, therefore, a good place to start thinking 'historically' about this particular, but often seemingly universal, aspect of masculinity.

The nineteenth-century 'career' politician grappled with a number of contradictory demands - many of them highlighting the tension between the calm, sedate (and indeed sedentary) nature of representative politics on the one hand, and the growing attention given to fitness, musculature and violence as aspects of 'natural' masculinity in the nineteenth century on the other, for example by jokingly referring to their own age-related infirmities. In 1865 these tensions rose to the surface in a rather atypically public display of contradictory masculinity in the Belgian hemicycle, and reported in the proceedings of the Chamber of Representatives (CoR). During a debate on the contested 'Mexican expedition' (in which a regiment of volunteers was recruited to 'save' princess Charlotte), representative Jan Delaet had targeted then minister of war Félix Chazal for the way in which recruitment had taken place. In retaliation, Chazal had called him “shameless” (CoR 5 April 1865, 759). This language was not up to the standards of dignity of parliament, according to his opponent, who demanded that the "infamous" term be "taken back" (CoR 5 Apr 1865, 768). The president of the Chamber seemed to be unable to ease the tension and Delaet 
eventually challenged Chazal to a duel to resolve the matter. Whilst the practice of duelling had largely disappeared in Belgium, and had indeed been made illegal in 1841, both seemed to agree on a physical reparation of their honour and the duel took place on April 8, 1865 (Van den Peereboom 1994, 86).

The outcome of their meeting was unspectacular: both men survived, and both seemed satisfied that their honour had been preserved - suggesting that the notion of parliamentary dignity was, at least in some circles, a masculine attribute that mirrored or perhaps modernised martial symbols of value and valour (La Vaque Manty 2006). More important than the event of the duel, however, is the particular context in which it could take place: in a representative democracy and more precisely in the legislative chamber that had outlawed the duel a couple of decades earlier. ${ }^{5}$ It is also important to note that it was instigated by a political figure who had made his name and career as a pacifist. Rather than two men battling in an attempt for hegemony, these seem to be participants in a 'community of communication' in which discourses of honour and dignity were closely intertwined and therefore (equally) attainable to both the military man and the political agitator (even if both parties would later attempt to mobilise various definitions of courage and danger to their own advantage). They both engaged in a process of cultural contestation against what the law and formal politics at the time defined as 'proper' masculine behaviour. Chazal would, in the wake of the duel, become the first Belgian minister to be brought in front of a judge during his tenure. Despite these official sanctions, however, both men seem to have been satisfied that their respective political and social constituencies recognised their behaviour as a display of authority and power (Hoegaerts 2011). Or, to put it simply, it did not do their careers and reputations any harm.

\section{Vocabularies of Masculinity and Work}

One of the more mundane, but nevertheless important problems of writing any history of masculinity is that of vocabulary. As is clear from the insistence on terms such as 'dignity', masculinity (unlike the more ideologically charged and

5 Duelling had been (and would continue to be in other countries for a while) a fairly common way to settle disputes. There are significant national differences in the cultural meaning of the duel and, therefore, the group of men most likely to engage in it. In addition to military men, journalists and politicians were seen as particularly likely to settle their disputes through duelling in the Francophone world (Hoegaerts, 2011). 
therefore more visible 'manliness', Tosh 1994) did not carry much meaning, nor, for that matter, did the notion of a 'career'. Historians of medieval and early modern masculinities, in particular, have called attention to the much more common use of terms like manliness, manhood and virility. Whilst these may seem to refer to norms and discourses of masculinity, it is important to keep in mind that they were part of a world in which 'biological' definitions of gender were not entrenched in the same way they would become from the late eighteenth century onward (a binary Thomas Laqueur (1990) would identify as a modern 'two-sex-model ${ }^{6}$ ). Terms such as manliness and virility are therefore not just different, older, terms for what is at heart the same mode of distinction, they bring to light profound cultural differences between current notions of 'biological' sex and its entanglements with gender identity and gendered practices, and those of the past. (Notably, women born into positions of authority were occasionally described as having 'manly' characteristics in the Early Modern period.) And whilst those differences are most striking for more remote periods of history, they are also present in 'modern' histories in which the socalled two-sex model was already in place. Even in the nineteenth century, when 'masculinity' would find a place in the various dictionaries, the word was very rarely used. The notion of any one term referring to characteristics of 'men' as a group would still have been largely foreign to a society as divided by class and race as the 'modern' European nation. The idea that men of the serving and ruling classes 'shared' masculine traits would only be expressed later. Space, emotions, practices and cultural references were shared more within 'communication communities' than they were among men across these communities (even if, within communication communities, gendered differences were of course observed, lived and expressed). In the First World War, 'serving' came to be connected to patriotic duties as much as it had been with work and a 'brotherhood' among men became imaginable in the trenches (see Steedman 2007 on the history of the 'serving' classes).

6 The two-sex model replaced an earlier understanding of male and female reproductive anatomy that Laqueur calls the 'one-sex model': the differences between the male and female reproductive organs appear, in this model, as a matter of degree or development, with the female womb and ovaries represented as an inwardly grown penis and testicles. Whilst differences between women and men were of course observed and described before the eighteenth century, gender was not prescribed upon the individual and masculinity and femininity were neither seen as polar opposites, nor were they present as well-circumscribed categories. The notion that 'biology is destiny' is a profoundly modern one, founded upon the principles of disciplines like evolutionary biology and, of course, Freudian psychology. It was only in the nineteenth century that such understandings of the 'biology' of the sexes took hold, and even then aspects of environmental determinism remained influential alongside them. 
That 'masculinities' were multiple (i.e. that 'being a man' meant fundamentally different things for individuals of different income, religious community, background, etc) would have been far more commonplace to the (early)-modern observer than the notion that 'men' could be seen to intrinsically share any set of characteristics. The languages spoken in the Belgian hemicycle, for example (French and, occasionally, Dutch) did not even assign very particular meanings to the terms masculinite or mannelijkheid. It was simply defined as 'pertaining to men'. If a person's particular characteristics thought to be intrinsically gendered were referred to, virilité did most of the heavy lifting in French (Corbin, Courtine and Vigarello 2009). Dutch speakers would turn to compound words combining 'man' with qualities such as courage (mannenmoed), strength (mannenkracht) or labour (mannenwerk), showing that these qualities were imagined to be intimately connected to men's role in the world (Hoegaerts 2014, 36). It was only by the end of the nineteenth century - roughly around the introduction of both universal male suffrage and the military draft in a number of Western countries that 'men' (regardless of other social markers) came to be seen as a particular collective: those who served their country and - in return - could be considered citizens and involved in politics (Dudink, Hagemann and Tosh 2004). In some ways, modern representative politics created 'masculinity' as a unified category as much as biology and the two-sex model did.

Much like nineteenth-century upper-middle class men would not think of themselves as sharing 'masculinity' with those of the lower classes, they would not think of their role as MP's or in government as 'work' (for one thing, they did not get paid for it). In fact, not having to 'work' is what distinguished the gentleman from what was tellingly called the 'working' (or serving) class. They may very well have thought of their trajectory in politics as something to be undertaken professionally however, and that would to a degree imply expertise and, therefore, manliness. The ideological connection between being a 'man' and the ability to support a family was firmly entrenched in this period (even though the 'breadwinner'-model seems largely to have been a historical fiction, Vanhaute 1998). For this class of men 'work' was not a deciding factor in that equation, however. Their notion of gendered careers depended on different imageries of duty and privilege, and above all on the notions of dignity discussed above. (In addition, the term 'career' was generally used to denote one's life course, the action of moving - consciously - in a certain direction. The Oxford English Dictionary only starts to define career as 'working in a profession' in 1927.)

Dignity, though exclusive to a very particular group of men, was not so much a quality simply assigned to or presumed natural in these men. It was a quality to be acquired. It depended on exhibiting the kind of behaviour 
associated with the cultural 'work' of the political representative, but was - crucially - also connected to age or maturity. It depended on how they managed their particular 'careers' through a political life. Or, in other words, dignity can be seen as a particular intersection of gender, class and age (and, less obviously, ability and ethnicity) - or, to borrow Griffin's terminology, it was modulated by differences in access to particular practices of masculinity. Its accessibility was, however, not only limited to particular people, but also to particular circumstances - it also depended on the interpretative practices of the historical actors surrounding those men whose political career was sufficiently advanced to be recognisable to others as successful public figures.

Whilst the vocabulary of parliamentary dignity 'hides' its gendered qualities, it is often expressed through much more obviously marked terminology: that of fatherhood (or fatherliness). Although even in the late nineteenth century, upper middle class men were unlikely to express any shared experience of 'masculinity' with the lower classes, they did refer to metaphors of kinship that were current in other parts of society (such as the army) to speak about citizenship and political accountability. And whilst this, too, was a class-specific language (the fatherhood referred to calls upon notions of middle class domesticity and leadership - i.e. men were expected to preside over their businesses or constituents like they did over their nuclear family - rather than the simple fact of paternity), it was projected unto men of lower social status as well, and presented a shared value, legitimising elite men's claim to 'represent' the nation's family fathers. This legislative fiction of family fathers representing 'all' fathers (who in their turn each represented their families when dealing with the outside world) was accompanied by a similar legal fiction of the bon père de famille of Napoleonic law (comparable to the reasonable man in English law). Fatherliness, like dignity, therefore appeared as part of one's 'career' in life as a man, and provided one of the most powerful imageries through which 'masculinity', though unspoken and unmarked, could be represented.

Most indicative of this importance of the image of the 'father' was, perhaps, the way in which the terminology of paternity was used metaphorically - and also how this metaphor gradually lost its power at the turn of the twentieth century. This comes across in accounts of the dignity displayed by the 'fathers of the nation'. In 1873 Representative Barthélemy Du Mortier raised the issue of parliamentary dignity in a debate on the hygienic conditions of the physical room in which the representatives met. Weaving together notions of domestic responsibility, individual autonomy and national belonging, he appealed to a distinctly 'fatherly' construction of masculinity on which political dignity needed to be based. "We need to be masters of our own place", he stated, connecting the representative's 
authority in the Chamber to that of a father in his home (CoR 18 June 1873). And whilst this fatherly approach to political authority was mobilised by all representatives, it was projected most explicitly onto the members of the 1830 National Congress whose fatherhood was connected to their political 'labour' when they were welcomed to the Chamber, in 1880 with the words "You are the fathers of the fatherland, your work grows over the years and your sons, filled with gratitude, bless you" (CoR 12 August 1880).

\section{Stories of Change}

For nineteenth-century men, and particularly those invested in what would later be seen as a professional 'career', issues of time and processes of ageing were therefore intrinsically bound up with questions of gender (as was class). To think about being a 'man' was to imagine the acquisition of dignity, maturity and its various trappings such as offspring, wealth or power, depending on the context in which one's career was forged. Less than an identity, 'masculinity' in the modern period can be analysed as a process, and it therefore needs to be considered in conjunction with the rhythm of modern life and changing understandings of time. As studies of female and 'crip' time suggest (St Pierre 2015), the men we are interested in here are largely the ones setting the pace: elite men's time (often represented as linear progress, rather than cyclical), like their bodies, was 'unmarked' and therefore appears as neutral: it is the pace we have largely adopted as the yard-stick for historical time.

It is perhaps for this reason that their careers now just appear as a 'lifetime' or a natural ageing process. Nevertheless, studying the practices of even these 'great' men (and doing so through largely sanitised documents such as parliamentary proceedings) gives us glimpses of the bumps and turns in the learning process of becoming a man. It shows the performative quality of this seemingly smooth and simple passage of time. In the Chamber of Representatives, men whose identities and reputations would mark them out as 'hegemonic' still struggled with aspects of political practice (through illness, speech impediments, or nerves), saw their practices as fathers, husbands or factory-owners impact their political performances, or indeed gained and lost influence in parliament as their performances of authority and masculinity changed over time. Focussing on the process-like character of (modern) masculinity, its necessary and constant intersection with age, also almost immediately draws attention to its historical contingency. This makes Ben Griffin's alternative framework to analyse masculinity so promising for historical analysis in particular. All four of 
the aspects of masculinity he points to refer to processes, to cultural work or, ultimately, to 'change'. This encourages an analysis that has room for diversity and for the ways in which notions of 'being a man' were imagined before it became fixed as a seemingly biological category (i.e. always already shaped by other characteristics such as age, class, ethnicity, religion, etc) but above all draws attention to the temporal fluidity of gendered norms and expectations. ${ }^{7}$

In the case of nineteenth-century representative chambers, that change has remained largely hidden. The practices of representation were guided by longstanding traditions (Crewe 2005) or by formal rules (Gardey 2015), and it is only around the turn of the twentieth century that significant numbers of newcomers entered the chamber - thus visibly questioning these rituals and rules. Research on early lower-class, ethnically 'different' and female representatives very clearly show challenges to the ossified and gendered rules of a closely knit, elitist and exclusive community (e.g. Hurd 2000). Allowing for a more fine-grained analysis of masculinity, however, grants us insight into the less dramatic processes of change and contestation that took place throughout the nineteenth century - and lets us distinguish between projections of 'traditional' masculinity employed to prop up current imaginations of diversity, and the much more complicated reality of historical masculinity upon which we can build a critical analysis of current dichotomous discourses of 'traditional' privilege and 'modern' equality.

The Belgian case presents an interesting one in that regard, because we can follow the installation of an entirely new legislative chamber, in 1831, and its subsequent development quite closely. The nation itself was as new as the chamber, and was immediately constructed as a 'modern' one: a constitutional monarchy supported by a system of representative democracy. This meant crafting a base of citizens as well, the Belgian 'people' would have to be defined

\footnotetext{
7 Analyses of historical masculinities and manliness, particularly before the rise of the 'twosex model', are perhaps most easily imagined as intrinsically intersectional: in the absence of a unified, fixed category of gender, historical actors could make sense of their own gendered identity only in the context of other characteristics, or within their communication community. In other words, it was commonly accepted that an upper-class man's 'manliness' differed significantly from that of a male serf, no unified or biological category to which both belonged could be imagined until well into the eighteenth century. Whilst Crenshaw's (1989) concept of intersectionality therefore presents an important reminder to historians of gender that human experience always relies on different categories, axes of power and modes of oppression/privilege in interaction and co-construction with each other, the work of 'deconstructing' these categories and showing their fluidity in the first place is particular to the modern period, in which notions of gender and race came to be seen as fixed (and in which, of course, the historian herself has to confront her own categories of thought).
} 
and learn to recognise themselves as such. This turned out to be far less straightforward. The 'fathers of the nation' seem to have been recognised as Belgian without hesitation, but not everyone who lived and worked on Belgian soil in 1830 would automatically become a citizen. Women and children would remain excluded throughout the nineteenth century, and universal single suffrage for men was only made available in 1918. Whilst not having the vote would not necessarily exclude these groups from having the Belgian 'nationality', it does show how the nation was imagined as exclusive at its inception (and to what extent it was geared towards masculine citizenship). Later immigrants to the country would need to be 'naturalised' to become members of the nation and participate in its political practices. French-born Félix Chazal, the aforementioned minister of war, was one of them. After being active in the Belgian revolution and acting as a commander in the Belgian army for over a decade, he was naturalised in 1844.

Chazal's ease in gaining entrance to the Belgian army and nation would have at least partly have been due to the existing demand for military men: founding a nation also necessitated the founding of an army, and particularly the roles demanding experience of leadership were initially largely filled with French officers. Speaking the same language and sharing the culture of the Belgian upper and upper-middle class would have allowed them to be recognised very easily as figures of authority and leadership, and indeed as possessing the quality of virilité. This view did not extend to other 'naturalised' Belgians, however. In 1883, when the chamber debated the creation of a new geological map of Belgium (which would effectively define what was the 'stuff' of the nation), emotions ran high when the employment of British-born experts on the project was discussed. Representative and university professor Jean Joseph Crocq caused hilarity when he said

Yes, sirs, we have put our factory of new Belgians to work, in order to have one more member in the official committee for the geological map. It is a second-class Belgian.

(CoR June 7, 1883)

In a discussion with Gustave Rolin-Jacquemyns, a man who had built his career in law and politics rather than science, Crocq based his authority on his understanding of representative democracy and its close intertwinement with 'competence'.

Crocq: I speak with confidence, because I am voicing the opinion of the public

Rolin-Jacquemyns: It is the public opinion of a couple of geologists.

Crocq: It is the opinion of competent men, of the geological nation as it were.

Rolin-Jacquemyns: That is precisely what I would dispute. 
Again, the question here is not one of hegemony or marginality, or indeed one of hierarchy in society at large, but rather one of different communities of communication in which the gendered category of 'citizenship' is imagined differently. Scientific actors saw masculinity and expertise as closely intertwined and connected to citizenship and the nation (Zilles 2018). Crocq therefore interpreted the inclusion of 'foreign' (in this case British-born) men in what should be a 'national' field of science as an invasion in the nation's democratic space, an affront to citizenship and the masculine dignity attached to it. Rolin-Jacquemins, who described the project of the map as "a matter of scientific interest and of national glory" (CoR, April 5 1881) saw a clear distinction between a scientific community of experts (or 'competent men') and the national community of manly and glorious citizens served by the former. The connection between masculine rationality, independence and membership of the nation seems to have been far less stable than historians of modern citizenship and 'hegemonic' masculinity have supposed. Focusing on these moments of contestation as well as the importance of 'interpretive' practices allows for a more fine-grained account of the 'careers' of masculinity performed by elite men in nineteenth-century political contexts.

\section{Conclusion - Historical and Traditional Masculinity}

As the above shows, political careers in the nineteenth century were intrinsically ambiguous processes, and not easily classified as the kind of 'work' that would later be associated with the male breadwinner model. Nevertheless, the image of the good family father carrying responsibility for his whole family was central to representatives' sense of self: it defined their connection with the 'nation' and with men in vastly different social and financial circumstances. Unfortunately, research into the histories of work, professionalisation and industrialisation has largely remained curiously separate from histories of masculinity and citizenship. Although historiographical overviews and programmatic methodological reflections on the history of masculinity often point to the important connection between masculinity and 'work' that seems to have been forged in the nineteenth century, a systematic analysis of that connection is not yet available. Likewise, whilst studies of the 'making' of the working class or the experiences of working life, or histories of modern clerical professions often note the exclusively masculine character of many of the career-paths being 
formulated, they rarely hone in on the intrinsic connections between gender and labour at work in these contexts.

And yet, historicising precisely this intersection between masculinity, the modern career, fatherhood and citizenship, might be of particular importance for our understanding of masculinities today. Few things are quite so central to the amorphous, imagined conglomerate of characteristics that makes up what is sometimes referred to as 'traditional' masculinity. The 'traditional' man is, of course, the result of a practice of (collective) imagination, of 'invention of tradition', and therefore necessarily culturally specific and somewhat undefined. Nevertheless, particularly in the modern 'West' we seem to be haunted by the spectre of a particular 'traditional man': a breadwinner, of strong musculature, aggressive and gentlemanly, and an authoritative leader and father. Whilst it is understood that traditional and historical masculinity are different things, traditional masculinity still seems to be imagined as something of the (vague and undefined) past, something against which we can contrast the subtleties, nuances, internal conflicts and fluidity of masculinity as it is practiced now. And of course, most of the characteristics of this imagined traditional masculinity can be traced back in some way to very different historical contexts and periods showing just what a mongrel the 'traditional' man is. If traditional masculinity's narrative of gentlemanliness may be traced back to (mis)representations of knights and noblemen of the distant past; if the traditional aggression associated with masculinity can be connected to the military ideologies and practices surrounding industrialised warfare; the image of the breadwinner and the career-driven 'traditional' man quite probably traces back to the nineteenth century. Processes of organising labour and professionalisation in conjunction with modernised notions of representation and citizenship were, as shown above, deeply implicated with gendered practices across different communities of communication and resulting in different kinds of interpretative cultural work. The rise of the political career shows that this is a period when being a man and a political actor became a 'profession', and individual 'work' outside the home was imagined as central to being a 'man' - albeit not necessarily as the breadwinner that now seems so traditional.

Acknowledgements: This research has been funded by a grant from the European Research Council (CALLIOPE, ERC StG 2017). I would also like to thank Kadri Aavik, Janne Salminen and Eva Johanna Holmberg for their helpful comments and critiques. 


\section{References}

Beyen, Marnix. 2006. "De eerbiedwaardige onderbrekers. Ironie en pastiche in de Franse kamer van afgevaardigden, 1890." In Humor met een verleden, edited by Marnix Beyen and Johan Verberckmoes, Leuven: Leuven University Press.

Bordo, Susanne. 1999. The Male Body. A New Look at Men in Public and Private. New York: Farrar, Straus and Giroux.

Brod, Harry. 2002. "Studying Masculinities as Superordinate Studies". In Masculinity Studies \& Feminist Theory. New Directions, edited by Judith Kegan Gardiner, New York: Columbia University Press.

Connell, Raewyn. 1995. Masculinities. Berkeley and Los Angeles: University of California Press.

Connell, Raewyn, and James W. Messerschmidt. 2005. “Hegemonic Masculinity: Rethinking the Concept”. Gender and Society, 19: 829-859.

Corbin, Alain et al., eds. 2009. Histoire de la virilité (volumes I-III), Paris: Le Seuil.

Crenshaw, Kimberlé. 1989. "Demarginalizing the Intersection of Race and sex: A Black Feminist Critique of Antidiscrimination Doctrine, Feminist Theory and Antiracist Politics." University of Chicago Legal Forum 140: 139-167.

Crewe, Emma. 2005. Lords of Parliament. Manners, Rituals and Politics. Manchester: Manchester University Press.

Davidoff, Leonore, and Catherine Hall. 1987. Family Fortunes: Men and Women of the English Middle Class, 1780-1850. Chicago: University of Chicago Press.

Delumeau, Jean and Daniel Roche, eds. 1990. Histoire des pères et de la paternité. Paris: Larousse.

De Smaele, Henk. 2002.“De beroepspoliticus. Waarom 'de aristocratie’ onvermijdelijk is.” In Politieke representatie, edited by Henk De Smaele, and Jo Tollebeek, 109-121. Leuven: Leuven University Press.

Dinges, Martin ed. 2005. Männer - Macht - Körper: Hegemoniale Männlichkeiten vom Mittelalter bis heute. Frankfurt: Campus Verlag.

Dudink, Stefan. 1998. "The Trouble with Men: Problems in the History of Masculinity." European Journal of Cultural Studies 1(3): 419-431.

Dudink, Stefan, Karen Hagemann, and Anna Clark, eds. 2007. Representing Masculinity. Male Citizenship in Modern Western Culture. London: Palgrave-Macmillan.

Dudink, Stefan, Karen Hagemann, and John Tosh, eds. 2004. Masculinities in Politics and War. Gendering Modern History. Manchester: Manchester University Press.

Ellis, Heather. 2014. "Knowledge, character and professionalisation in nineteenth-century British science." Journal of the History of Education Society 43: 777-792.

Francis, Martin. 2002. "The Domestication of the Male? Recent Research in Nineteenthand Twentieth-Century British Masculinity", The Historical Journal 45(3): 637-652.

Frevert, Ute. 1991. Ehrenmänner. Das Duell in der bürgerlichen Gesellschaft. München: C.H. Beck.

Frevert, Ute. 2001. Die kasernierte Nation: Militärdienst und Zivillgesellschaft in Deutschland. München: C.H. Beck.

Gardey, Delphine. 2015. Le linge du palais Bourbon. Corps, matérialité et genre du politique à l'ère démocratique. Lormont: Le Bord de l'eau. 
Griffin, Ben. 2018. “Hegemonic Masculinity as a Historical Problem.” Gender \& History 30(2): 377-400.

Griffin, Ben. 2012. The Politics of Gender in Victorian Britain. Masculinity, Political Culture and the Struggle for Women's Rights. Cambridge: Cambridge University Press.

Griswold, Robert L. 1993. Fatherhood in America: A History. New York: Basic Books.

Hagemann, Karen. 2002. Männlicher Muth und Teutscher Ehre. Nation, Militär und Geschlecht zur Zeit der Antinapoleonischen Kriege Preussens. München: Schöningh.

Hall, Catherine. 1992. White, Male and Middle Class. Explorations in Feminism and History. Cambridge: Polity Press.

Handley, Sasha, Rohan McWilliam, and Lucy Noakes, eds. 2018. New Directions in Social and Cultural History. London: Bloomsbury.

Harvey, Karen, and Alexandra Shepard. 2005. "What Have Historians Done with Masculinity? Reflections on Five Centuries of British History, ca. 1500-1950." Journal of British Studies 44(2): 274-280.

Hoegaerts, Josephine. 2012. "Benevolent Fathers and Virile Brothers: Metaphors of Kinship and the Construction of Masculinity and Age in the Nineteenth-Century Belgian Army." BMGN-Low Countries Historical Review 127(1): 72-100.

Hoegaerts, Josephine. 2011 "L'homme du monde est oblige de se battre. Duel-vertogen en praktijken in en rond het Belgische parlement, 1830-1900." Tijdschrift voor Geschiedenis 124: 190-205.

Hoegaerts, Josephine. 2014. Masculinity and Nationhood. Constructions of Identity and Citizenship in Belgium 1830-1910. London: Palgrave Macmillan.

Hurd, Madeleine. 2000. "Class, Masculinity, Manner and Mores. Public Space and Public Sphere in Nineteenth-Century Europe." Social Science History 24(1): 75-110.

Kennedy, C., and Matthew McCormack, eds. 2007. Public Men. Masculinity and Politics in Modern Britain. London: Palgrave Macmillan.

Kimmel, Michael. 1996. Manhood in America: A Cultural History. New York: Free Press.

Knibiehler, Yvonne. 1987. Les pères aussi ont une histoire. Paris: Hachette.

Lauwers, Karen. 2019. "Negotiating the Republic: Direct Interactions Between Unorganized Citizens and MPs in France, ca.1900-1930s." PhD diss., University of Antwerp.

La Vaque-Manty, Mika. 2006. “Dueling for Equality”, Political Theory 34(6): 715-740.

Laqueur, Thomas W. 1990. Making Sex: Body and Gender from the Greeks to Freud. Cambridge: Harvard University Press.

Lees, Clara A. ed. 1994. Medieval Masculinities: Regarding Men in the Middle Ages. Minneapolis: University of Minnesota Press.

Lenzen, Dieter. 1991. Vaterschaft. Vom Patriarchat zur Alimentation. Reinbek: Rowohlt.

Mangan, J.A. 2000. Making European Masculinities: Sport, Europe, Gender. London: Frank Cass.

Mazo Karras, Ruth. 2002. From Boys to Men. Formations of Masculinity in Late Medieval Europe. Philadelphia: University of Pennsylvania Press.

Mosse, George. 1996. The Image of Man. The Creation of Modern Masculinity. Oxford: Oxford University Press.

Nye, Robert. 1993. Masculinity and Male Codes of Honour in Modern France. Oxford: Oxford University Press.

Rauch, André. 2000. Le premier sexe. Mutations et crise de l'identité masculine.

Paris: Hachette. 
Richter, Hedwig and Kerstin Wolff, eds. 2018. Frauenwahlrecht. Demokratisierung der Demokratie in Deutschland und Europa. Hamburg: Hamburger Edition.

Roper, Michael. 2005. "Between Manliness and Masculinity: The 'War Generation' and the Psychology of Fear in Britain, 1914-1950." Journal of British Studies 44: 343-362.

Rotundo, E. Anthony. 1993. American Manhood: Transformations in Masculinity from the Revolution to the Modern Era. New York: Basic Books.

Smith, Bonnie. 2000. The Gender of History. Men, Women and Historical Practice. Cambridge, MA: Harvard University Press.

Schnicke, Falko. 2015. Die männliche Disziplin. Zur Vergeschlechtlichung der deutschen Geschichtswissenschaft (1780-1900). Göttingen: Wallstein.

Scott, Joan Wallach. 1986. "Gender: A Useful Category of Historical Analysis." American Historical Review 91(5): 1053-1075.

Shepard, Alexandra. 2006. Meanings of Manhood in Early Modern England. Oxford: Clarendon Press.

Solomon-Godeau, Abigail. 1997. Male Trouble. A Crisis in Representation. New York: Thames and Hudson.

Szreter, Simon. 1995. Fertility, Class and Gender in Britain 1860-1940. Cambridge: Cambridge University Press.

Steedman, Carolyn. 2007. Master and Servant: Love and Labour in the English Industrial Age. Cambridge: Cambridge University Press.

Surkis, Judith. 2006. Sexing the Citizen. Morality and Masculinity in France, 1870-1920. Ithaka and London: Cornell University Press.

St Pierre, Joshua. 2015. "Distending Straight-Masculine Time: A Phenomenology of the Disabled Speaking Body." Hypatia. A Journal of Feminist Philosophy 30(1): 49-65.

Theweleit, Klaus. 1977. Männerphantasien. Verlag Roter Stern: Frankfurt am Main.

Tosh, John. 1994. "What Should Historians Do with Masculinity? Reflections on NineteenthCentury Britain." History Workshop Journal 38(1): 179-202.

Tosh, John. 2007. A Man's Place: Masculinity and the Middle-class Home in Victorian England. New Haven: Yale University Press.

Tosh, John. 2015. The Pursuit of History. Aims, Methods and New Directions in the Study of History, Routledge.

Traister, Bryce. 2000. “Academic Viagra: the Rise of American Masculinity Studies” American Quarterly 52(2): 274-304.

Van den Peereboom, Alphonse. 1994. La fin d'un règne: notes et souvenirs, edited by Marcel Bots, Ghent: Liberaal Archief.

Vanhaute, Eric. 1998. "Het kostwinnermodel als historische fictie. Arbeid en inkomen van gezinnen in langetermijnperspectief." In Het kostwinnersmodel voorbij? edited by Walter Van Dongen e.a. 55-71. Leuven: Garant.

Witte, Els, Jan Craeybeckx and Alain Meynen. 2009. Political History of Belgium: From 1830 onwards. Brussels: VUBPress.

Zilles, Sebastian. 2018. Die Schulen der Männlichkeit. Männerbünde in Wissenschaft und Literatur um 1900. Vienna and Cologne: Böhlau Verlag. 